\title{
Clinicopathological properties of Non-Hodgkin Lymphomas in the south-west of Turkey
}

\author{
Erdal Kurtoğlu ${ }^{1}$, Mustafa Yıldırım² ${ }^{2}$ Hülya Karakılınç ${ }^{3}$, Mustafa Yıldız ${ }^{4}$, Sevil Göktaş ${ }^{4}$, \\ Dinç Süren ${ }^{5}$, Vildan Kaya ${ }^{6, *}$
}

${ }^{1}$ Antalya Education and Research Hospital, Department of Hematology, Antalya, Turkey

${ }^{2}$ Ministry of Health Batman Regional Government Hospital, Department of Medical Oncology, Batman, Turkey

${ }^{3}$ Antalya Provincial Health Directorate, Cancer Registration Center, Antalya, Turkey

${ }^{4}$ Antalya Education and Research Hospital, Department of Medical Oncology, Antalya, Turkey

${ }^{5}$ Antalya Education and Research Hospital, Department of Pathology, Antalya, Turkey

${ }^{6}$ Süleyman Demirel University School of Medicine, Department of Radiation Oncology, Isparta

\section{Email address:}

vildansimsir@yahoo.com(V. Kaya)

\section{To cite this article:}

Erdal Kurtoğlu, Mustafa Yıldırım, Hülya Karakılınç, Mustafa Yıldız, Sevil Göktaş, Dinç Süren, Vildan Kaya. Clinicopathological Properties of Non-Hodgkin Lymphomas in the South-West of Turkey. Cancer Research Journal. Vol. 1, No. 2, 2013, pp. 15-19. doi: $10.11648 /$ j.crj.20130102.11

\begin{abstract}
Objective: Non-Hodgkin Lymphomas, which have numerous histological subgroups, entail various biological behaviour, clinical properties and epidemiological differences. Incidence of histological subtypes can vary according to geographical locations. In this article, we will discuss clinicopathological properties of Non-Hodgkin Lymphoma patients in Antalya, which is located in the south-west of Turkey. Material and Method: This study used the data from 1994 to 2010 on the patients from the data bank of Turkish Ministry of Health, Antalya Provincial Health Directorate, Cancer Registration Center. Results: The study covered a total of 1521 patients, including 899 (59.1\%) male and 622 (40.9\%) female patients. One-hundred thirty (8.6\%) of the patients were under the age of 20, $911(60 \%)$ were aged between 20-65, and 477 (31.4\%) were above the age of 65. Cellular origins of Non-Hodgkin Lymphomas were evaluated in 1518 patients. B-cell originated Non-Hodgkin Lymphoma was identified as the most common with $86.4 \%$ (Table 1). We also revealed that T-cell originated Non-Hodgkin Lymphomas were more common under the age of 20. Conclusions: Clinicopathologic properties of Non-Hodgkin Lymphomas vary across countries as well as across regions in a country. We believe that such differences should be taken into account in the diagnosis and treatment of these patients.
\end{abstract}

Keywords: Lymphoma, Non-Hodgkin, South-west Turkey, Pathologic Processes

\section{Introduction}

Incidence of lymphomas, (which are solid tumours of lymphocytes those are important elements of the immune system), varies according to age, geographical location and exposure to various viral factors. Lymphoma types which belongs to the group of is a heterogeneous disease, has two main types, which namely are Non-Hodgkin Lymphoma [NHL] and Hodgkin Lymphoma [HL]. NHL, which comprises $85 \%$ of all lymphomas, with an occur 6.5 in 100.000 in males and 4.4 in females, according to 2006 data from Turkey [1]. It accounts for $3-4 \%$ of all cancers around the world [2].
NHL incidence has shown to be on the rise. In the US, its incidence has increased by $80 \%$ from 1973 to 2000 . This increase is related to the increase in HIV incidence as well as the prevalant use of immune-suppressive drugs [3,4].

NHL has numerous histological subgroups, entails various biological behaviours, clinical properties and epidemiological differences. Incidence of histological subtypes can vary according to geographical locations $[5,6]$. In this article, we will discuss the clinicopathologic findings of NHL patients in Antalya, which is located in the southwestern of Turkey. 


\section{Material and Method}

This study used the data for the years 1994-2010 from the data bank of Turkish Ministry of Health, Antalya Provincial Health Directorate, Cancer Registration Centre. The centre collects data according to the population-based cancer recording standards of World Health Organization's International Cancer Research Agency. Patients who were histopathologically diagnosed with NHL from 1994 to 2010 were included for the study.

The patients were evaluated in terms of age, gender, histological subtype, primary diagnosis site and extranodal involvement. The study included patient cases 2001 and 2008 WHO classification of NHL pathology. The histological subtypes were assessed by gender. The patients were separated to 3 different subgroups according to their age, 0-20, 20-65 and above 65, and the distribution of histological subtypes among these groups was evaluated, and finally statistical analyses were conducted with SPSS 13.0 .

\section{Results}

The study covered total of 1521 patients were involved in the study; 899 [59.1\%] male and 622 [40.9\%] female patients. The male/female ratio was 1.44 . The median age of the patients was 57 [1-93]. 130 [8.6\%] of the patients were under the age of 20,911 [60\%] were aged between 20-65, and 477 [31.4\%] were above the age of 65 . Cellular origins of NHLs were evaluated in 1518 patients. B-cell originated NHL was identified as the most common with $67 \%$ while T-cell originated NHLs were more common under the age of 20 [Table 1].

$9.5 \%$ of patients were diagnosed with T-cell lymphoma. The most common subtype of T-cell lymphomas was the mycosis fungoides with 41 patients [28.9\%]. The second most common subtype was the anaplastic large-cell lymphoma with 30 patients [Table 2]. The histological subtype information of 913 patients diagnosed with B-cell lymphoma was obtained. The most common subtype Diffuse Large B-cell lymphoma of which 441 patients [43.4\%] [Table 3]. The other more common B-cell lymphomas were the chronic lymphocytic leukaemia/chronic lymphocytic lymphoma [CLL/SCL] $(10.9 \%)$ and follicular lymphoma $(10.3 \%)$.

In $98.5 \%$ of the patients, the lymph node or involvement was diagnosed via organ biopsies, while 22 patients were diagnosed through cytological investigations. Nodal involvement was identified in 1016 patients [66.8\%], while extranodal involvement was diagnosed in 505 patients [33.2\%]. The most common extranodal involvement site was identified as the stomach; accounting for [30.2\%], while the other common extranodal involvement sites were the skin [13\%], the small intestine [8.5\%], nasopharynx, nasal cavity $[8.6 \%]$ and the central nervous system [7\%].

In patients whose nodal involvement site information was available, the most common nodal involvement site was the head and neck region with $27.8 \%$, followed by axillary [9.5\%] and inguinal [8.2\%] regions.

Age distribution by histological subtypes were also studied [Table 4]. 52 patients were diagnosed with Burkitt Lymphoma, which included 35 male [67.3\%] and 17 female [32.7\%] patients. The median age of the patients was 12 [range: 3-76], while the average age of patients diagnosed with intestinal lymphoma was $48.6 \pm 19.5$.

\section{Discussion}

The median age in our study was 57 , which is consistent with the western data [7]. Previous studies in Turkey have identified a median age at earlier ages as compared to the western data. Işıkdoğan et al. have reported the median age to be 43, while Barışta et al. as 44, and Sarpel et al. as 45.5 in males and 41.1 in females $[8,9,10]$. These studies were conducted in the central, southern and south-eastern Turkey. A study conducted in western Turkey registered a median age of 55 [11]. The age patern of NHL incidence increases from the east to the west of the country, and the findings is in agreement with those reported in western literature. Some histological subgroups are identified at earlier ages. Our study has found the median age of Burkitt lymphoma as 12 , while follicular lymphoma occurs at more advanced ages. In our study, the average incidence age of follicular lymphoma was found as 62 , which is also consistent with the data extracted from western nations [12].

NHLs are lympho-proliferative diseases derived from Blymphocytes, T-lymphocytes and Natural Killer [NK] cells. The incidence frequencies with regard to the cellular origins of NHLs varies across different parts of the world [6]. In the US, $80-85 \%$ of NHLs are derivated from B-cells, while $15-20 \%$ are from T-cells [7]. In our study, B-cell origins were found as $86.4 \%$, and T-cell origins as $12 \%$, which is consistent with figures from the western literature. Upon investigating the cellular origins with respect to age groups, we have revealed that T-cell originated NHLs are more common under the age of 20 , which, we believe, is due to high incidence of intestinal lymphomas in early ages.

The nature of NHL, histological subtypes of NHL is also influenced by geographical factors. For example, Burkitt Lymphoma is identified at 5.7-7.6 per 100.000 individuals in Africa, while the incidence is only around 0.22 in Europe $[13,14]$. Follicular lymphomas are more common in Europe and in the USA while it is rare in Africa, China and the Middle East [15,16]. Despite it being the second most common subtype of NHL [17]. In our study, we found follicular lymphoma among B-cell lymphomas as the third most common subtype with $9.8 \%$. In their study, Iş1kdoğan et al. found this incidence as $6.1 \%$. In this study, we found SLL/CLL with a higher ratio of $19.4 \%$, which is above the ratios reported by Barışta et al.

Mantle-cell lymphoma comprises $50 \%$ of all lymphomas of the gastrointestinal system, and has an incidence of $7 \%$ among all NHLs [18]. Our study has found a lower incidence of $3.4 \%$ of Mantle-cell lymphoma than the ratios 
reported in literature. Diffuse large cell lymphoma is the most common B-cell lymphoma, and is identified at $31 \%$ among all NHLs. Our study as well as the study by Işıkdoğan has identified this incidence around $40 \%$. In the study by Barışta, a DBBHL incidence of $30.1 \%$ was identified, which is consistent with the western literature.

Among T-cell lymphomas, the angioimmunoblastic Tcell lymphoma is found at $20 \%$ [19]. In our study, it was found as $9.1 \%$, which is lower in the study of Iş1kdoğan et al. with $0.6 \%$.

NHL usually involves the lymph nodes; however, extranodal involvement is observed in $20-30 \%$ of patients $[20,21]$. There was a three-fold more increase in extranodal involvement ratios, as compared to nodal involvement [22]. The most increasing extranodal involvement is in the central nervous system, which is considered to be related with the increase in HIV infections [23]. The most common primary extranodal lymphoma involvement sites are the stomach, small intestine, skin and central nervous system [24]. Incidence of extranodal involvement varies across countries. In the USA, the incidence is $24 \%$, while it is $44 \%$ in Lebanon [25]. A high incidence of gastric lymphoma is identified in the north-western part of Italy [26]. We also found an extranodal involvement ratio of $33.2 \%$, which is found as $44 \%$ in the study by Işıkdoğan, similarly with the Middle Eastern countries. Our study has found the most common site of extranodal involvement as the gastrointestinal system with $43.8 \%$. Sixty-nine percent of all gastrointestinal system involvement was the gastric lymphoma. Arican et al. found the incidence of gastric involvement as $66 \%$ in a study in Ankara [27]. Similar incidences were demonstrated in studies by Eser et al. and Erkut et al. [28,29]. Dinçol et al., unlike these studies, found the most common site of gastrointestinal involvement as the small intestine [30]. Paydas et al., however, identified the stomach as the most common site of gastrointestinal involvement [31]. In their study, the average age of patients of gastric lymphoma was found as 47.1. In our study, there was approximately 10 years of difference with the said study. Similar findings were revealed for the involvement of the small intestine. The primary lymphomas of the small intestine are common in the Middle Eastern countries, and the average age of incidence is 25 . The average age was found at more advanced ages in the study by Paydas et al. as well as in our study. The average incidence age for primary lymphomas of the small intestine also increases from the western to the eastern parts of Turkey.

\section{Conclusions}

Clinicopathologic properties of NHLs vary across countries as well as across regions in a country. We believe that such differences should be taken into account in the diagnosis and treatment of these patients.

The authors declare that they have no conflict of interest.
Table 1. Cellular differentiation by age groups

\begin{tabular}{lllll}
\hline Cell Origin & $\begin{array}{l}\mathbf{0 - 2 0} \\
\text { old } \\
\text { N/\% } \%\end{array}$ & $\begin{array}{l}\text { years20-65 } \\
\text { old } \\
\text { N/\% }\end{array}$ & $\begin{array}{l}\text { years } \\
\text { 65 years old } \\
\text { N/\% }\end{array}$ & $\begin{array}{l}\text { Whole } \\
\text { Group } \\
\text { N/\% }\end{array}$ \\
\hline B-cell & $77(59.2)$ & $614(67.4)$ & $327(68.6)$ & $1018(67)$ \\
T-cell & $19(14.6)$ & $89(9.8)$ & $36(7.6)$ & $144(9.5)$ \\
$\begin{array}{l}\text { Undifferentiat } \\
\text { ed }\end{array}$ & $2(0.8)$ & $7(0.8)$ & $7(1.6)$ & $16(1)$ \\
$\begin{array}{l}\text { Missing } \\
\text { Total }\end{array}$ & $33(25.4)$ & $201(22)$ & $106(22.2)$ & $340(22.5)$ \\
\hline
\end{tabular}

Table 2. Distribution of patients with T-cell lymphomas among subtypes

\begin{tabular}{lcc}
\hline \multicolumn{1}{c}{ Histological Subtype } & N & T cell (percent) \\
\hline Anaplastic large-cell lymphoma & 30 & 21.2 \\
Angioimmunoblastic lymphoma & 13 & 9.1 \\
Intestinal T hc lymphoma & 3 & 2.1 \\
Cutaneous T-cell lymphoma & 4 & 2.8 \\
T-cell with unidentified subtype & 29 & 20.4 \\
Mycosis Fungoides & 41 & 28.9 \\
NK/T-cell nasal type & 4 & 2.8 \\
Precursor T-cell lymphoblastic & 16 & 11.3 \\
\hline
\end{tabular}

Table 3. Distribution of patients with B-cell lymphoma among subtypes

\begin{tabular}{lcc}
\hline Histological Subtype & N & B cell (percent) \\
\hline $\begin{array}{l}\text { Burkitt lymphoma } \\
\begin{array}{l}\text { Splenic marginal zone } \\
\text { lymphoma }\end{array}\end{array}$ & 52 & 5.2 \\
$\begin{array}{l}\text { Follicular lymphoma } \\
\begin{array}{l}\text { Diffuse large B-cell } \\
\text { lymphoma }\end{array}\end{array}$ & 105 & 0.7 \\
$\begin{array}{l}\text { Mixed Large- and } \\
\text { Small-cell Lymphoma }\end{array}$ & 441 & 10.3 \\
$\begin{array}{l}\text { Small-cell lymphoma } \\
\text { Lympho-plasmocytic } \\
\text { lymphoma }\end{array}$ & 58 & 43.4 \\
$\begin{array}{l}\text { Mantle cell lymphoma } \\
\text { Marginal zone } \\
\text { lymphoma }\end{array}$ & 111 & 5.7 \\
$\begin{array}{l}\text { Primary mediastinal B- } \\
\text { cell lymphoma }\end{array}$ & 9 & 10.9 \\
$\begin{array}{l}\text { Missing } \\
\text { Total }\end{array}$ & 50 & 0.8 \\
\hline & 94 & 2.9 \\
\hline
\end{tabular}


Table 4. Age distribution of histological subtypes

\begin{tabular}{|c|c|c|}
\hline Histological Subtype & $\begin{array}{c}\text { Average } \pm \text { Standard } \\
\text { Deviation }\end{array}$ & Median \\
\hline Burkitt lymphoma & $20.1 \pm 19.2$ & 12 \\
\hline $\begin{array}{l}\text { Splenic marginal zone } \\
\text { lymphoma }\end{array}$ & $61 \pm 7.8$ & 64 \\
\hline Follicular lymphoma & $59.3 \pm 14.6$ & 62 \\
\hline $\begin{array}{l}\text { Diffuse large B-cell } \\
\text { lymphoma }\end{array}$ & $55.8 \pm 16.7$ & 59 \\
\hline Small-cell lymphoma & $55.7 \pm 16.5$ & 58.5 \\
\hline $\begin{array}{l}\text { Lymphoplasmacytic } \\
\text { lymphoma }\end{array}$ & $59.6 \pm 11.9$ & 64 \\
\hline Mantle cell lymphoma & $56.7 \pm 16.5$ & 58 \\
\hline $\begin{array}{l}\text { Marginal zone } \\
\text { lymphoma }\end{array}$ & $54.3 \pm 16.7$ & 62 \\
\hline $\begin{array}{l}\text { Intestinal } \mathrm{T} \text { hc } \\
\text { lymphoma }\end{array}$ & $48.6 \pm 19.5$ & 40 \\
\hline Mycosis Fungoides & $49.5 \pm 15.3$ & 48 \\
\hline Primary cutaneous & $53.7 \pm 11.7$ & 53 \\
\hline Central Nervous System & $53.3 \pm 15.2$ & 55 \\
\hline Gastric involvement & $57.3 \pm 15.5$ & 61 \\
\hline $\begin{array}{l}\text { Small intestine } \\
\text { involvement }\end{array}$ & $42.7 \pm 19.9$ & 44 \\
\hline
\end{tabular}

\section{References}

[1] Eser S, Yakut C, Özdemir R, et al. Cancer incidence rates in Turkey in 2006: a detailed registry based estimation. Asian Pac J Cancer Prev 2010; 11: 1731-9.

[2] Ferlay J, Shin HR, Bray F, Forman D, Mathers C, Parkin DM. Estimates of worldwide burden of cancer in 2008: GLOBOCAN 2008. Int J Cancer 2010; 27: 2893-7.

[3] Clarke CA, Glaser SL, Dorfman RF, Bracci PM, Eberle E, Holly EA. Expert review of non-Hodgkin's lymphomas in a population-based cancer registry: reliability of diagnosis and subtype classifications. Cancer Epidemiol Biomarkers Prev 2004; 13: 138-43.

[4] Altekruse SF KC, Krapcho M, Neyman N, eds. Cancer Statistics Review 2007; 1975-2007.

[5] Naresh KN, Srinivas V, Soman CS. Distribution of various subtypes of non-Hodgkin's lymphoma in India: a study of 2773 lymphomas using R.E.A.L. and WHO Classifications. Ann Oncol 2000; 11: 63-7.

[6] Anderson JR, Armitage JO, Weisenburger DD.Epidemiology of the non-Hodgkin's lymphomas: distributions of the major subtypes differ by geographic locations. Non-Hodgkin's Lymphoma Classification Project. Ann Oncol 1998; 9: 717-20.

[7] Jemal A, Siegel R, Xu J, Ward E (2010). Cancer statistics,
2010. CA Cancer J Clin 2010; 60: 277-300.

[8] Isikdogan A, Ayyildiz O, Buyukcelik A, et al. NonHodgkin's lymphoma in southeast Turkey: clinicopathologic features of 490 cases. Ann Hematol 2004; 83: 265-9.

[9] Barista I, Tekuzman G, Firat D, et al. Non-Hodgkin's lymphomas in Turkey:eighteen years' experience at the Hacettepe University. Jpn J Cancer Res 1994; 85: 1200-7.

[10] Sarpel SC, Paydas S, Tuncer I, Varinli S, Koksal M, Akoglu T. Non-Hodgkin's lymphomas in Turkey. Cancer 1988; 62: 1653-7.

[11] Alici S, Bavbek SE, Kaytan E, Başaran M, Eralp Y, Onat H (2002). Aggressive non-Hodgkin's lymphoma treated at the Institute of Oncology, Istanbul: treatment, outcome, and prognostic factors. Am J Clin Oncol, 25, 502-8.

[12] Armitage JO (1997). A clinical evaluation of the International Lymphoma Study Group classification of nonHodgkin's lymphoma. The Non-Hodgkin's Lymphoma Classification Project. Blood, 89, 3909-18.

[13] Orem J, Mbidde EK, Lambert B, de Sanjose S, Weiderpass E. Burkitt's lymphoma in Africa, a review of the epidemiology and etiology. Afr Health Sci 2007; 7: 166-75.

[14] Sant M, Allemani C, Tereanu C, et al. HAEMACARE Working Group. Incidence of hematologic malignancies in Europe by morphologic subtype: results of the HAEMACARE project. Blood 2010; 116: 3724-34.

[15] Shih LY, Liang DC. Non-Hodgkin's lymphomas in Asia. Hematol Oncol Clin North Am 1991; 5: 983-01.

[16] Ho FC, Todd D, Loke SL, Ng RP, Khoo RK. Clinicopathologic features of malignant lymphomas in 294 Hong Kong Chinese patients, retrospective study covering an eight-year period. Int J Cancer 1984; 34: 143-8.

[17] Piccaluga PP, Sapienza MR, Agostinelli C, et al. Biology and treatment of follicular lymphoma. Expert Rev Hematol 2009; 2: 533-47.

[18] Armitage JO, Weisenburger DD. New approach to classifying non-Hodgkin's lymphomas: clinical features of the major histologic subtypes. Non-Hodgkin's Lymphoma Classification Project. J Clin Oncol 1998; 16: 2780-95.

[19] Dorfman DM, Brown JA, Shahsafaei A, Freeman GJ. Programmed death-1 (PD-1) is a marker of germinal centerassociated $\mathrm{T}$ cells and angioimmunoblastic T-cell lymphoma. Am J Surg Pathol 2006; 30: 802-10.

[20] Weisenburger DD. Epidemiology of non-Hodgkin's lymphoma:recent findings regarding an emerging epidemic. Ann Oncol 1994; 5: 9-24.

[21] Groves FD, Linet MS, Travis LB, Devesa SS. Cancer surveillanceseries: non-Hodgkin's lymphoma incidence by histologicsubtype in the United States from 1978 through 1995. J Natl Cancer Inst 2000; 92:1240-51.

[22] Devesa SS, Fears T Non-Hodgkin's lymphoma time trends:United States and international data. Cancer Res 1992; 52: $5432 \mathrm{~s}-40 \mathrm{~s}$.

[23] Hartge P, Devesa SS, Fraumeni Jr JF. Hodgkin's and nonHodgkin's lymphomas. Cancer Surv 1994; 20: 423-53.

[24] Vose JM, Chiu BC, Cheson BD, Dancey J, Wright J. Update 
on epidemiology and therapeutics for non-Hodgkin's lymphoma. Hematology Am Soc Hematol Educ Program $2002 ; 241-62$.

[25] Zucca E, Cavalli F Extranodal lymphomas. Ann Oncol 2000; 11: $219-22$

[26] Doglioni C, Wotherspoon AC, Moschini A, de Boni M, Isaacson PG. High incidence of primary gastric lymphoma in northeastern Italy. Lancet 1992; 339: 834.

[27] Arican A, Dinçol D, Akbulut H, et al. Clinicopathologic features and prognostic factors of primary extranodal nonHodgkin's lymphomas in Turkey. Am J Clin Oncol 1999; 22: 587-592.

[28] Eser B, Kaplan B, Unal A, et al Clinicopathologic characteristics and therapeutic outcomes of primary gastrointestinal non-Hodgkin's lymphomas in central Anatolia, in Turkey. Yonsei Med J 2006; 47: 22-33.

[29] Erkurt MA, Aydogdu I, Kuku I, Kaya E, Basaran Y. Clinicopathologic characteristics and therapeutic outcomes of primary gastrointestinal non-Hodgkin's lymphomas: 10 years of experience from a single center in eastern Anatolia. Med Princ Pract 2009; 18: 399-406.

[30] Dinçol D, Içli F, Erekul S, et al. Primary gastrointestinal lymphomas in Turkey: a retrospective analysis of clinical features and results of treatment. J Surg Oncol 1992; 51: 270-273.

[31] Paydas S, Kekec Y, Zorludemir S. Gastrointestinal lymphoma in southern Turkey. Cent Afr J Med 1996; 42: $56-60$. 